\title{
Sources of Financing High-Tech Projects
}

\author{
Elena Alexandrovna Rybkina ${ }^{1}$, Olga Vladimirovna Demyanova ${ }^{1}$ \& Julia Vladimirovna Babanova ${ }^{2}$ \\ 1 Department of Production Economics, Institute of Economics and Finance, Kazan (Volga region) Federal \\ University, Kazan, Russia \\ ${ }^{2}$ Department of Industrial Economics and Project Management Institution, Federal State Autonomous Educational of \\ Higher Education, South Ural State University (National Research University), Kazan, Russia \\ Correspondence: Elena Alexandrovna Rybkina, Candidate of Economic Sciences, Associate Professor, Associate \\ Professor of the Department of Production Economics, Institute of Economics and Finance, Kazan (Volga region) \\ Federal University, Kazan, Russia. Tel: 7-917-394-7104.
}

Received: September 1, 2020

Accepted: October 10, 2020

Online Published: November 30, 2020

doi:10.5430/ijfr.v11n6p177

URL: https://doi.org/10.5430/ijfr.v11n6p177

\begin{abstract}
This article is aimed at considering current sources of financing for high-tech projects. In the article, statistical data confirm the orientation of developed and developing countries' economies towards the generation of high-tech products by the dynamics of added value in high-tech and medium-high-tech industries, respectively - support for high-tech manufacturing enterprises and industries as a whole. Lists of high and medium-high-tech adopted sectors in the Russian Federation, in the United States, and in European nations, and a list of critical technologies are given. Special attention is given to the essence of the high-tech projects, concept, through the implementation of a rise in the share of high-tech products. The article identifies the main characteristics that distinguish a high-tech project from an innovative one. The dynamics of value-added in high-tech and medium-high-tech sectors of the economies of developing and developed countries are studied in conjunction with $\mathrm{R} \& \mathrm{D}$ spending in high-tech sectors of these countries. On the example of the United States (the global leader in the high-tech industry), the structure of financing high-tech projects carried out by companies at the expense of internal financing, that is, own funds is investigated. Based on the Russian Federation, the volumes of attracted cash in the form of grants and the amount of borrowed cash in the form of a subsidy for the implementation of high-tech projects in dynamics for 2012-2018 are investigated.
\end{abstract}

Keywords: high-tech technology, high-tech companies, high-tech projects, high-tech products, sources of financing, innovation, grants, subsidies, funds

\section{Introduction}

In case of a change in the world's technological dominance, the transition from a resource economy to an innovative economy, that is, the formation of non-resource global competitive industries, special attention is spent on breakthrough technologies. The creation, use, and improvement of these technologies may significantly enhance the functional, technical, and economic parameters of technical systems or create fundamentally new systems with previously unattainable capabilities. Some of them relate to critical technologies that have crucial socio-economic significance or special significance for state security.

Simultaneously, the core of the sixth technological mode must be microworld technologies (convergence of nano-, bio-, information and cognitive technologies (NBIKS-convergence, NBIC) (Glazyev \& Kharitonova, 2009); social, humanitarian technologies; new medicine, household appliances, modes of transport and communications; use of stem cells, living tissue and organ engineering, reconstructive surgery and medicine (Glazev, 1993 \& Grinin et al., 2016). Industries that intensively use these technologies, and implement technological innovations in them, have a pivotal role in the dissemination of a new technological structure and are bearing industries the scientific works of Glazyev S.Yu evidence this. (Decree of the President of the Russian Federation), and the legislative acts that determine the strategic guidelines of the country in the field of scientific and technological development confirm [Decree of the Government of the Russian Federation]:

- Technological updating of traditional industries [Decree of the Government of the Russian Federation];

- An expansion in the share of products of new high technology manufacturing and knowledge-intensive services in the gross domestic product based on structural transformations in the country's economy [Decree of the Government of 
the Russian Federation];

- Growth in export revenues of high technology products, services and technology intellectual rights [Decree of the President of the Russian Federation of December].

\section{Methods}

The study is carried out based on:

- conceptual analysis (the terms high-tech industr», high-tech organization, high-tech products, high-tech project);

- database compilation of the Federal State Statistics Service of the Russian Federation, Unified interdepartmental information and statistical system, European Union Statistical Office, World Bank Group, National Center for Science and Engineering Statistics, systematization and analysis of statistical data.

\section{Results and Discussion}

High-tech projects are increasingly discussed in the context of the transition to the sixth technological paradigm and project management methodology. Nevertheless, there is no specific interpretation of the «high-tech project» concept in the scientific literature. Therefore, some authors link it with an innovative or high technology project. For instance, they associate high-tech projects with projects implemented in high technology or high technology organizations (companies). However, as noted by several authors (Garina et al., 2016 \& Kuznetsov, 2015), this is not entirely correct, since the fact that manufacturing is knowledge-intensive does not automatically mean that it is high technology manufacturing (Garina et al. 2016). Alternatively, all projects implemented by high-tech organizations (companies) automatically become high-tech. Table 1 compares the concepts of project, innovation project, high-tech project, and also distinguish their main distinctions. When considering the data of table 1 , it should be noted that the list of characteristics is not finite, but is formed from the most striking/inherent characteristics.

Table 1. Comparative table of the concept's characteristics: project, innovative project, high-tech project

\begin{tabular}{|c|c|c|c|}
\hline Characteristic & $\begin{array}{l}\text { Project }[15, \\
16, \text { p.37] }\end{array}$ & $\begin{array}{l}\text { Innovation } \\
\text { project [17] }\end{array}$ & $\begin{array}{l}\text { High-tech } \\
\text { project [18-20] }\end{array}$ \\
\hline Activity, activity & + & + & + \\
\hline Effectiveness (Success / Failure) & + & + & + \\
\hline Timing (start date, end date) & + & + & + \\
\hline Uniqueness (innovativeness) of the result / product / service & + & + & + \\
\hline Resources limited & + & + & + \\
\hline High risk & $+/-$ & $+/+$ & $+/+$ \\
\hline Increased risk of design process & - & + & + \\
\hline Relevance & - & + & + \\
\hline Organizational and technological complexity & - & + & + \\
\hline $\begin{array}{l}\text { Innovative approaches and solutions are used in the } \\
\text { implementation process }\end{array}$ & - & + & - \\
\hline $\begin{array}{l}\text { The inability to fit the project into well-structured, accepted } \\
\text { methods, techniques of design, project management }\end{array}$ & - & + & + \\
\hline $\begin{array}{l}\text { Knowledge-intensive } \\
\text { (the need for deep scientific studies) }\end{array}$ & - & - & + \\
\hline Implemented by high technology organizations (companies) & - & - & + \\
\hline The implementation process uses high technology & - & - & + \\
\hline The result is a high technology product & - & - & + \\
\hline
\end{tabular}

"-" is an optional / unprincipled characteristic;

"+" is a mandatory / principal characteristic.

Thus, high-tech projects are fundamentally different from innovative ones in that:

- High technologies are applied in the process of the project implementation;

- High technology product is created as a result of the project implementation. 
In fact, it is more correct to say innovative project in a high-tech industry, innovative project in a high technology company or innovative project in the area of high technologies. At the same time, high technology is the initial idea, the starting point for the implementation of future high technology, and innovation is the first attempt to put the technology into practice. The innovation project, in turn, is a means of transition from the development of high-tech R\&D to the commercialization of innovation (Laptev, 2007 \& Christensen, 2004).

However, the question arises, what about high technology? According to the dictionary [Collins Dictionary]:

- $\quad$ high technologies (high technology, high-tech, hi-tech) - these are very complex technologies, often including electronics and robotics, used in production and other processes;

- low technologies (Low technology, low tech) - relatively simple technologies that use equipment and production technologies (as opposed to high technologies), limited to the production of basic necessities.

International and federal statistical organizations [European Union Statistical Office \& Unified interdepartmental information and statistical system] distinguish high technology manufacturing and knowledge-intensive sectors. Simultaneously, a high-tech industry implies an industry with a high level of technological growth, defined by the ratio of R \& D costs to gross value added [The calculation method of the indicators ]and relatively low material and labor (Laptev, 2007). High-tech industries include high-tech and medium-high-tech industries. Meanwhile, the classifying of high-tech industries is of special significance. For instance, the «quota of high-tech and knowledge-intensive industries» in the gross domestic product of a country and / or gross regional product of a country's case is one of the indicators defining the efficiency of the economies of the world. Table 2 displays the industries of the economy associated with high-tech sectors, from the view of the Russian Federation and member states of the Organization for Economic Cooperation and Development (from now on OECD).

In the USA, industries of high technological level involve communications and semiconductors, aircraft and spacecraft, computers and office machinery, navigation, measuring pharmaceuticals, medical, optical, and measuring equipment. And to industries of a medium-high technological level involve motor vehicles and parts, electrical machinery and appliances, chemicals excluding pharmaceuticals, machinery and equipment, railroad and other transportation equipment.

Note that the difference in the names of industries that are part of the high and medium high is not significant and not fundamental.

Table 2. List of high-tech industries

\begin{tabular}{ll}
\hline OKVED* code & $\begin{array}{l}\text { Industries of high technological level, medium-high technological level for } \\
\text { calculating the indicator"Quota of high-tech products in GDP / GRP." }\end{array}$ \\
\cline { 2 - 2 } & In Russia Comparable to recommended indicators for OECD countries \\
\hline High technology industries \\
\hline Industries of high technological level \\
\hline 21 & Production of medicines and materials utilized for medical schemes \\
\hline 26 & Production of computers, optical products, and electronic \\
\hline 30.3 & Production of aircraft, including spacecraft, and related equipment \\
\hline Industries of medium-high technological level \\
\hline 20 & Production of chemicals and chemical products \\
\hline 25.4 & - Production of weapons and ammunition \\
\hline 27 & Production of electrical appliances \\
\hline 28 & Production of machinery and equipment nec \\
\hline 29 & Production of trailers, motor vehicles, and semi-trailers \\
\hline 30 without 30.3) & $\begin{array}{l}\text { Production of other vehicles and equipment, excluding 30.3 (manufacture of } \\
\text { aircraft, including spacecraft, related equipment) }\end{array}$ \\
\hline 32.5 & Production of medical instruments and equipment \\
\hline 33 & Repair and installation of machinery and equipment \\
\hline
\end{tabular}

* Russian Classification of Economic Activities 
However, not all organizations/companies belonging to the industries listed in Table 2 can be considered high-tech and moreover, not all projects initiated and implemented by these companies can be considered high-tech.

A high-tech organization/company is characterized by:

- The main activity, including the implementation, implementation and support of projects for the introduction of new or significantly improved technologies.

- The use by the company in its production of key technology, which is part of the national List of critical technologies in force at the time of the launch of its goods and / or services on the market (table 3). It is important to note that in the literature leading technologies are often referred to as key (or critical) (Laptev, 2007). Therefore, in the future, we will adhere to precisely this terminology.

Table 3. The critical technologies list of the Russian Federation [Decree of the President of the Russian Federation]

№ Critical technology title

1. Essential and significant military and industrial technologies for generating assuring types of weapons, military, and specialized equipment.

2. Essential technologies of electrical power engineering.

3. Biocatalytic, biosensor, and biosynthetic technologies.

4. Veterinary and biomedical technologies.

5. Genomic, postgenomic, and proteomic technologies.

6. Cellular technology.

7. Computer simulation of nanomaterials, nanodevices, nanotechnology.

8. Nano, bio, cognitive, and information technologies.

9. Technologies of the nuclear fuel cycle, nuclear energy, safe management of radioactive waste and spent nuclear fuel.

10. Bioengineering technologies.

11. Diagnostics technologies for nanomaterials and nanodevices.

12. Technologies for access to broadband multimedia services.

13. Technology information, control, navigation systems.

14. Technologies of nanodevices and microsystem technology.

15. Technologies of brand-new and renewable energy sources, such as hydrogen energy.

16. Technologies for obtaining and processing structural nanomaterials.

17. Technologies for the production, processing of functional nanomaterials.

18. Technologies and software for distributed and highly productive computing systems.

19. Technologies for monitoring and calculating the status of the environment, prevention, and removal of its pollution.

20. Technologies for prospecting, examination, improvement of mineral deposits, as well as their extraction.

21. Technologies for the prevention and liquidation of natural and technogenic emergencies.

22. Technologies to reduce losses from socially significant diseases.

23. Technologies for creating high-speed vehicles and intelligent control systems for new modes of transport.

24. Technologies for creating a new generation of aerospace, transport equipment.

- The ability not only to offer fundamentally new products and / or services on the market, but also to harmonize its commercial goals (such as making a profit from its core business) with the strategic interests of the state in the formation of industrial and trade policies focused not only on sustainable, but also the progressive development of the world economy.

- The level of knowledge-intensive technologies (the share of costs (at least 3,5\%) for research and development, referred to production results) used by companies in their production. If it exceeds $8,5 \%$, then this production is 
the leading of knowledge-intensive technology (leading edge) (Vovchenko, 2005), if the knowledge-intensive level of technology is 2,5\%, then the average level, if 0,5\%, then the low level (Vovchenko, 2005 \& Bendikov \& Frolov, 2001) As a result, the presence in the economic activity of technical know-how, innovative developments.

- The level of knowledge-effectiveness is perceived as the rate of the volume of sales of high-tech products to R \& $\mathrm{D}$ costs for a certain period (basically a year). The standard for the effectiveness of knowledge transfer is the relative extension in sales of a new (from the standpoint of the next generation of technical products qualitatively different from the former one) high-tech commodities with high consumer qualities in the market as opposed to the development of the whole high-tech market (involving out-of-date products developed earlier yet still sold on the market. (Laptev, 2007)

- High level of qualification of employees and its continuous growth in accordance with dynamically changing market requirements.

- Maintaining close ties with the academic environment, conducting joint fundamental research, cooperation with leading universities.

- High speed of changes, improvement of products, technologies, i.e. shorter life cycle.

This list is not mutually exclusive in nature, but rather complementary.

It turns out that a high-tech organization should belong to a high-tech industry (Table 2) and use key (critical) technologies (Table 3). At the same time, the data in Table 3, as it were, concretizes the high-tech industries of Table 2, limiting the circle of high-tech organizations. However, the use of technologies in the project and / or process activities alone does not say anything about the organization's R\&D expenses and the level of innovation activity. For example, pharmaceutical companies in the Russian Federation are often engaged in packaging products, rather than developing new products or manufacturing those (Adamajtis et al., 2019). This explanation should be taken into account when interpreting the results of this article. Thus, the key importance is seen, taking into account high-tech projects implemented using critical technologies (table 3 ) and aimed at creating high-tech products (project results).

High-tech products - products in the generation of which high technologies are included, and the industries accountable for creating such products occupy an essential place in the modern economy (Kvacheva, 2008 \& Buravlev, 2019).

At the legislative level, the criteria for classifying goods, work and services as high-tech products in Russia are:

- The goods are manufactured, the work is performed, the service is provided by companies of high-tech and high-tech industries utilizing technologies and / or facilities that correspond to the preferred areas for the advancement of science, technology and technology and / or the list of significant technologies of the Russian Federation supported by the President of the Russian Federation(table 2) [Decree of the President of the Russian Federation];

- The goods are manufactured, the work is performed, and the service is provided using the latest samples of technological equipment, technological processes, and technologies [Decree of the Government of the Russian Federation].

In scientific literature, high-tech products are characterized by:

- The level of high technology (the quota of research and development costs related to production results) is at least 3.5\% [Federal State Statistics Service of the Russian Federation].

- The level of knowledge-effectiveness - the ratio of the volume of sales of high-tech products to R \& D expenses for a specific period (normally a year). The basis for the effectiveness of knowledge-effectiveness is the comparable growth in sales of a new (from the viewpoint of the next generation of technical products qualitatively different from the previous one) high-tech goods with high consumer characteristics in the market, in contrast to the increase of the entire high-tech market (including old products developed earlier although still sold on the market) (Vovchenko, 2005).

Thus, to consider the sources of financing high-tech projects, under high-tech projects will mean projects implemented by organizations belonging to the high-tech industries of the list of Table 2, during the implementation of which critical technologies are used from the list of Table 3 and / or as a result of the implementation of which high-tech products are created characterized by a high level of knowledge-intensive (> 3.5) and a high level of knowledge-effectiveness.

Since 2002, the global result of high-tech industries possesses more than doubled. Figure 1 reveals the dynamics of high-tech enterprises' added value in nations, including the United States, Great Britain, China, Japan, Brazil, Germany, France, Russia, India, Malaysia, for the period 2011-2018. 


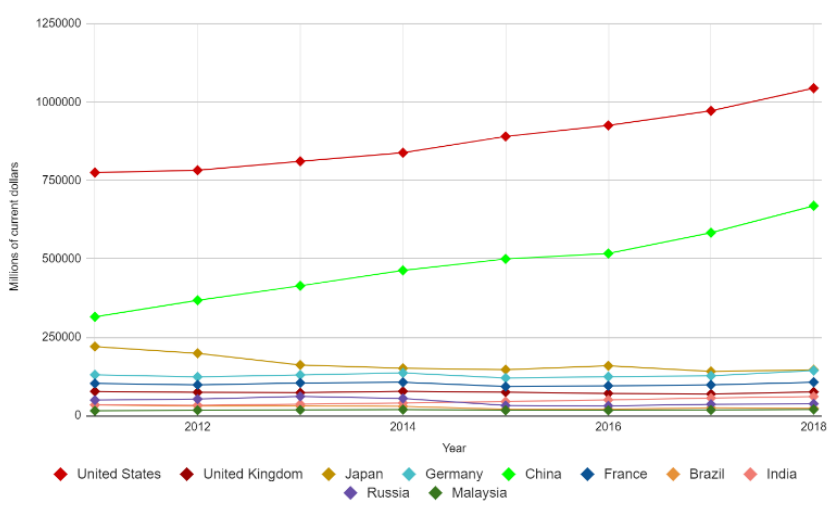

Figure 1. Value added of high R\&D intensive industries, by country, 2011-2018 [National Center for Science and Engineering Statistics]

Overthe last thirty years or so, the United States has been the world's largest producer of output products in industries with a high technological level. It considers for almost a third of the world's production of these industries. The second-largest manufacturers are China and European countries (Germany, France, etc.). Figure 2 exhibits the value of the dynamic added of medium-high technology industries in lands such as the United States, Malaysia, China, France, Great Britain, Japan, Germany, Russia, Brazil, and India for 2011-2018.

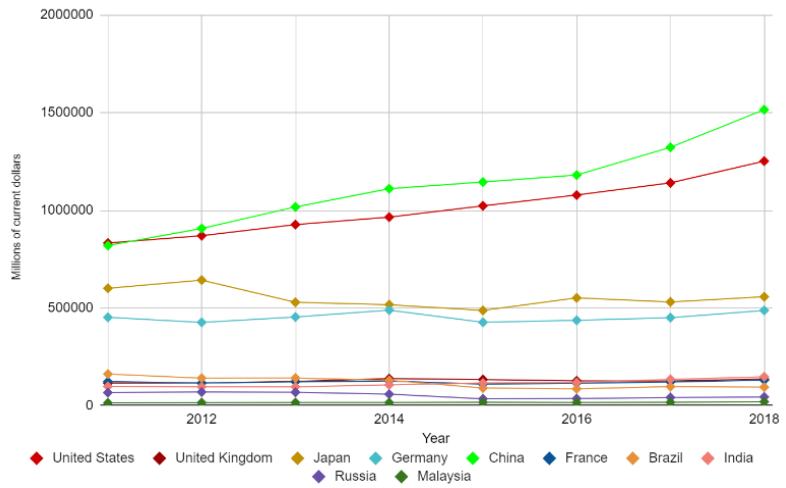

Figure 2. Value added of medium-high technology industries by country, 2011-2018 [National Center for Science and Engineering Statistics]

The diagrams of Figures 1 and Figures 2 clearly demonstrate the growth in project implementation in high-tech and medium-high-tech industries around the world and global leaders: United States, China, Japan, Germany. The revealed dynamics of sales volumes of products must be correlated with the dynamics of R \& D expenses in high-tech industries (Figure 3). 


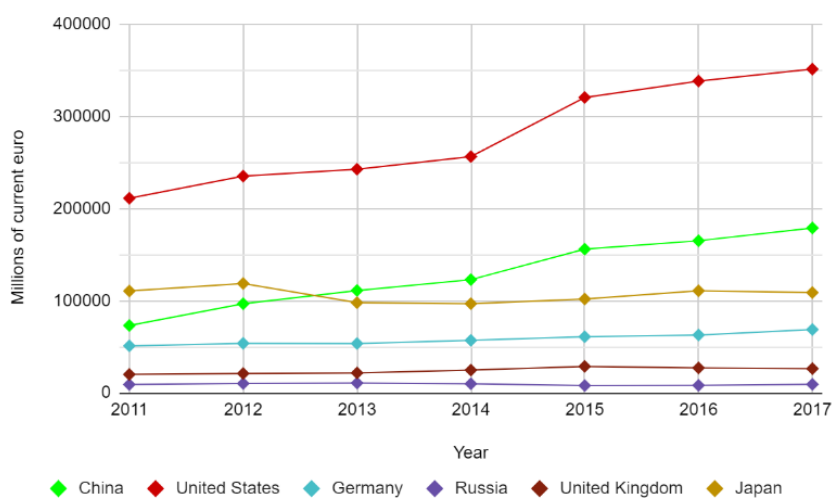

Figure 3. Value of enterprise spending on research and development in high-tech sectors, 2011-2017 [European Union Statistical Office \& World Bank Group]

Thus, the market volume of industries with a high technological and medium-high technological level is growing; countries are becoming involved in a technological race, involving more and more resources, including financial ones. According to the World Bank (Laptev, 2007 \& World Bank Group), the leaders in terms of total spending on research and development are the United States, Japan, and Germany among European countries. Currently, developed countries spend significant R\&D funds. There are four main centers of scientific research in the world: the USA (31\% of world R\&D expenses), the European Union (24\%), China (14\%) and Japan (11\%). These costs for most developed countries range from 3.5 to $1,5 \%$ of GDP. The share of Russia is less than $2 \%$.

In matters of financing, it is important to understand that money is allocated for the implementation of a specific innovative project in the field of high technologies with a specific result (high-tech product), but not for financing high-tech enterprises or entire industries. The structure of relevant and main sources of financing is presented in Figure 4.

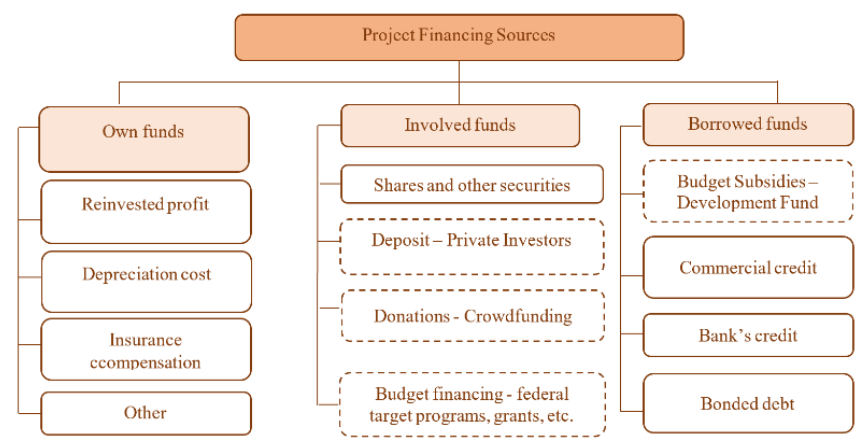

Figure 4. Project financing sources (Koval'chuk \& Stepnov, 2016; Volab, 2014)

The information in Figure 4 is classic. However, the blocks highlighted by dashed lines have found active distribution in recent years.

It is worth mentioning that the majority of the research and development of high-tech companies in the United States is carried out at the expense of internal financing, that is, at the expense of companies' own funds. This is confirmed by the statistics converted to Figure 5. In the high technological level sectors, the quota of domestic funding is 54\%, and in the medium-high technological sectors - 23\%. In Figure 5, funds provided by other sources are not included. 


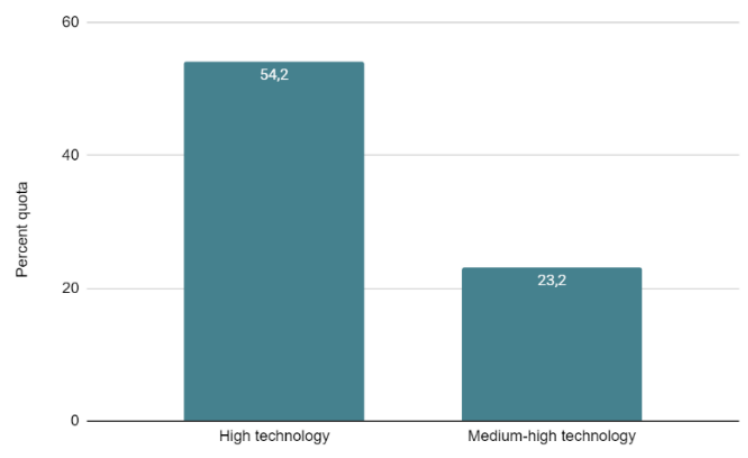

Figure 5. Quota of high-tech industries in the USA financed at the expense of companies own funds, 2016 [National Center for Science and Engineering Statistics]

However, in matters of financing high-tech projects, a significant role is played by the state, which distributes grants for the implementation of basic research. The proportion of such funding varies significantly across countries. For example, in Israel, basic research is $25-30 \%$ funded by the state through grants. The rest is funded through international projects. About 70 venture funds are actively working in the country, 14 of which are international. In 2010, 391 Israeli high-tech companies raised $\$ 1,26$ billion (Volab, 2014).

In the Russian Federation, financing:

- Fundamental and exploratory research projects are carried out by state funds: Russian Foundation for Basic Research (RFBR); Russian Science Foundation (RSF);

- State-owned funds are involved in applied research projects: Foundation for Assistance to Small Innovative

Enterprises (FASIE); Federal state Autonomous Institution «Russian Foundation for Technological Development» (Industrial Development Fund); Advanced Research Foundation (ARF).

Also, private foundations such as the National Technology Initiative (NTI) Project Support Fund and the Fund for Development of the Center for Elaboration and Commercialization of New Technologies (Skolkovo Foundation) provide financial support for high-tech applied projects. Information on these organizations is presented in Figure 6.

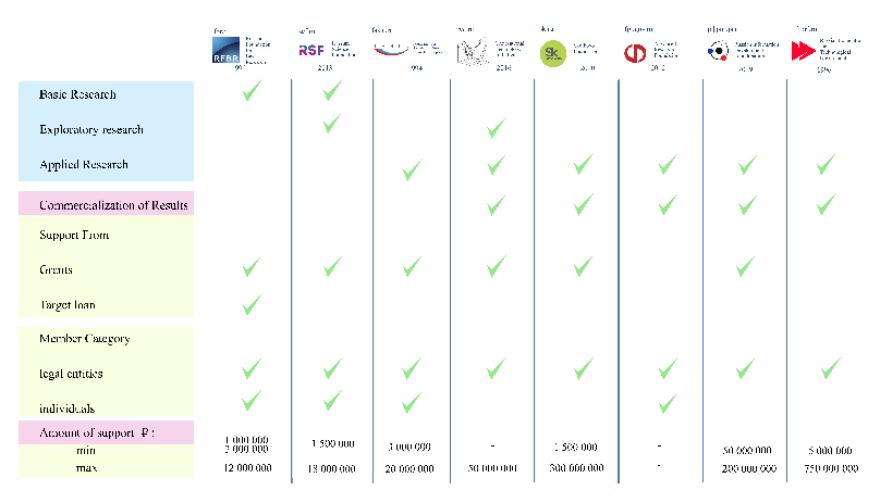

Figure 6. Comparative characteristics of non-profit organizations financing high-tech projects in the Russian Federation

In Figure 6, the list of organizations financing the implementation of high-tech projects includes the Industrial Development Fund. It differs from all other forms of support. From this list, only this organization issues subsidies, not grants, which is an example of borrowed funds for the implementation of the project, but different from a bank's credit.

The amount of funding for high-tech projects, including fundamental, exploratory, fundamental research, in the Russian Federation is shown in Figure 7. 
Over 7 years, the total funding of high-tech projects in the Russian Federation has grown by almost 4 times. The growth was formed mainly due to an increase in the volume of budget funds allocated to finance fundamental, search and applied research projects implemented within the framework of critical technologies (table 3).

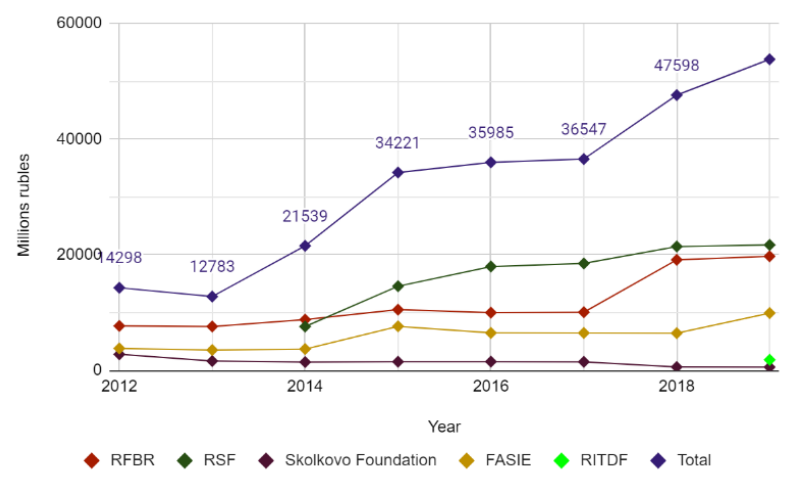

Figure 7. The volume of financing for high-tech projects, 2012-2018

As a source of attracted financial resources for high-tech projects, one can note crowdfunding and initial coin offering (ICO). Investors' interest is enhanced by the development and growth of cryptocurrencies, as well as the policies of some of the leading countries that support the cryptocurrency circulation and operations with them. However, rather it is an instrument of the future. There are no significant volumes attracted for the implementation of high-tech projects.

\section{Summary}

Through the study, the concept of high-tech project has been fully explained. In fact, this is a project executed by an organization belonging to the high-tech industry from the list of Table 2. Moreover, the implementation utilizes critical technologies from the list of Table 3 or generates high-tech products characterized by state-of-the-art technology (> 3.5) and a high level of knowledge efficiency.

Global leaders demonstrating the growth of project implementation in high-tech and medium-high-tech industries are the United States, China, Japan, and Germany. Undoubtedly, attracted financial resources from state and private funds in the form of grants play a significant role in matters of financing high-tech projects. Less popular among private investors, but quite popular among large corporations, are borrowed funds in the form of subsidies for the creation of high-tech products. The newest and not yet developed is the crowdfunding tool. In the United States, high-tech industries have a fairly high level of domestic financing. Its share is $54 \%$, and in the medium-high-tech - $23 \%$.

\section{Conclusion}

It is recommended that when choosing sources of financing for high-tech projects, pay attention to:

- Level of technological readiness (maturity) of a high-tech product - TRL 6 and above;

- Export potential or import substitution potential;

- The attraction of extrabudgetary financing along with state financing, the share of which should be at least $50 \%$ of the total investment;

- Scaling the results of high-tech projects;

- The potential for the commercialization of project results in high-tech sectors of the economy;

- The ability to overcome technological barriers in the industry through the implementation of high-tech projects.

\section{Conflict of Interest}

The authors declare no conflict of interest.

\section{Acknowledgment}

The survey is conducted based on the Russian Government Program of Competitive Growth of Kazan Federal University. 


\section{References}

Adamajtis, S. A., Barinova, V. A., Zemcov, S. P., Kidyaeva, V. M., Kocyubinskij, V. A., et al.. (2019). National report "High-tech business in the areas of Russia". M.: RANHiGS, AIRR.

Archibald, R. D. (2017). Managing high-technology programs and projects.

Bagrinovskij, K. A., Bendikov, M. A., \& Hrustalev, E. Y. U. (2003). Mekhanizmy tekhnologicheskogo razvitiya ekonomiki Rossii: Makro i mezoekonomicheskie aspekty.

Bainbridge, M. S., \& Roco, M. C. (2005). Managing Nano-Bio-Info-Cogno Innovations: Converging Technologies in Society. NY: Springer.

Bendikov, M. A., \& Frolov, I. E. (2001). High-tech product markets: trends and development prospects.

Buravlev, A. I. (2015). Management of High-Tech Projects at the Stage of Research and Development, 3(33).

Buravlev, A. I. (2019). Modeli upravleniya resursnym obespecheniem proektov sozdaniya vysokotekhnologichnoj produkcii. Vooruzhenie I Ekonomika, 4(50), 62-71.

Christensen, C. M. (2013). The innovator's dilemma: when new technologies cause great firms to fail. Harvard Business Review Press.

Collins Dictionary. (n.d.). Retrieved from https://www.collinsdictionary.com/dictionary

Decree of the Government of the Russian Federation of 15.06.2019 N 773. (2019). On the criteria for classifying goods, works, services as innovative products and (or) high-tech products. Retrieved from https://www.garant.ru/products/ipo/prime/doc/72170780

Decree of the Government of the Russian Federation of March 29, 2019 N 377. (2019). On approval of the state program of the Russian Federation Scientific and technological development of the Russian Federation. Retrieved from https://base.garant.ru/72216664

Decree of the President of the Russian Federation of 07.07.2011 N 899. (2015). On the approval of priority areas for the development of science, technology and technology in the Russian Federation and the list of critical technologies of the Russian Federation. Retrieved from http://www.kremlin.ru/acts/bank/33514

Decree of the President of the Russian Federation of 07.07.2011 N 899. (2015). On the approval of priority areas for the development of science, technology and technology in the Russian Federation and the list of critical technologies of the Russian Federation. Retrieved from http://www.kremlin.ru/acts/bank/33514

Decree of the President of the Russian Federation of December 1, 2016 No. 642. (2016). On the Strategy for Scientific and Technological Development of the Russian Federation. Retrieved from http://www.kremlin.ru/acts/bank/41449

Decree of the President of the Russian Federation of May 7, 2018 No. 204. (2018). On national goals and strategic objectives of the development of the Russian Federation for the period until 2024. Retrieved from http://www.kremlin.ru/acts/bank/41449

Dubickaya, E. A., \& Cukanova, O. A. (2019). Guidelines for Managing Innovative Projects in High-Tech Industries, 1, 21-25.

European Union Statistical Office, Eurostat. (n.d.). Retrieved from https://ec.europa.eu/eurostat/cache/metadata/en/htec_esms.htm

Federal State Statistics Service of the Russian Federation. (n.d.). Retrieved from https://www.gks.ru

Ganguli, I. (2017). Saving Soviet science: The impact of grants when government R\&D funding disappears. American Economic Journal: Applied Economics, 9(2), 165-201.

Garina, E. P., SHpilevskaya, E. P., \& Andryashina, N. S. (2016). Vestnik Mininskogo Universiteta, 1(13).

Glazev, S. Y. (1993). Theory of longterm technical-economic development.

Glazyev, E. S. Y., \& Kharitonova, V. V. (2009). Nanotechnology as a key factor in the new technological order in the economy. Trent, 304.

Gracheva, O. V., Glebova, O. V., \& Melnikova, O. Y. (2019). Voprosy Innovatsionnoy Ekonomiki, 9(3), 1067-1076. https://doi.org/10.18334/vinec.9.3.41013

Grinin, L. E., Korotaev, A. V., \& Grinberg, R. S. (2016). Crises and forecasts in the light of the theory of long waves. 
Gurieva, L. K. (2004). Technology concept. Innovacii, 10, 70-75.

Konochkina, T. V. (2009). Formation of a production program for the production of high-tech products, avtoref. Chelyabinsk: South Ural state. Univ, 26.

Koval'chuk, Y. U. A., \& Stepnov, I. M. (2016). Rynochnoe finansirovanie vysokotekhnologichnyh proektov (pp. 73-78).

Kudryavtseva, S. S., Galimulina, F. F., Zaraychenko, I. A., \& Barsegyan, N. (2018). Modeling the Management System of Open Innovation in the Transition to E-economy. Modern Journal of Language Teaching Methods, 8(10), 163-171.

Kuznetsov, V. P., Romanovskaya, E. V., Vazyansky, A. M., \& Klychova, G. S. (2015). Internal enterprise development strategy. Mediterranean Journal of Social Sciences, 6(S3), 444.

Kvacheva, Y. U. I. (2008). Pricing method for new high-tech durable goods.

Laptev, A. A. (2007). The Concept of the "high-tech company". Modern Microeconomics, 7(105), 35-41.

National Center for Science and Engineering Statistics (NCSES). Retrieved from https://ncses.nsf.gov/pubs/nsb20205/production-patterns-and-trends-of-knowledge-and-technology-intensive-in dustries

PMBOK, P. (2013). A Guide to the Project Management Body of Knowledge. Project Management Institute.

Rybkina, E. A., \& Gilmutdinov, S. R. (2014). Upravlenie proektami: oblast', metodologiya, Sistema. Project management: area, methodology, system. Vestnik Ekonomiki, Prava I Sociologii, 1, 36-39.

Shenhar, A. J., \& Dvir, D. (2007). Reinventing project management: the diamond approach to successful growth and innovation. Harvard Business Review Press.

Unified interdepartmental information and statistical system. (n.d.). Retrieved from https://www.fedstat.ru

Vasilenko, V. (2013). Technological structures in the context of the desire of economic systems for ideality. Social'no-Ekonomichni Problemi I Derzhava, Ternopol, 1(8), 65-72.

Volab, C. (2014). Prioritet Nor-organizaciya finansirovaniya vysokotekhnologichnyh proektov. The Priority of NRA is the Organization of Financing High-Tech Projects, 5(51), 16-29.

Vovchenko, V. V. (2005). The main directions and prospects of development of the world and Russian high technology market.

World Bank Group. $\quad$ (n.d.). $\quad$ Retrieved from https://databank.worldbank.org/source/world-development-indicators/preview/on

\section{Copyrights}

Copyright for this article is retained by the author(s), with first publication rights granted to the journal.

This is an open-access article distributed under the terms and conditions of the Creative Commons Attribution license (http://creativecommons.org/licenses/by/4.0/). 